\title{
素粒子論の基礎について I
}

\section{湯川秀 樹}

\section{1. 素粒子と素過程}

自然的世界の基碟構造を開明しようとする科学者の努 力は, 古代の哲学者の原子のイメージを具体化し, 精密 化与る方向に漸次集約されてきた. 十九世紀の末から今 日までの間に科学者のいうところの原子は物質構造の最 穹極者としての地位を完全に喪失し，これに代って素粒 子が最め重要な役割を荷うこととなった。しかしそれは も以や古代哲学者の原子の再現ではなかった. 原子の二 つの基本的属性一一即ちそれが分割不可能であること及 び永久不変であること一一ので，第二の属性は明らか に素粒子には適用できない，今日素粒子と認められてい るものの中には，中性子や中間子のように自発的に他の 粒子に転化するものがある. 最近数年間に次々と見出さ れた新しい粒子は，いずれる極めて短時間に自己崩壊す るわのばかりである、これ等の粒子の中の少なくとも幾 つかは素粒子であろうという推定を認めるならば，不安 定であることの方がむしろ素粒子の通有性で，陽子や電 子のように自己崩壤しないわのの方が例外的存在である という見方さえできるのである，そればかりではない。 それ自身としては安定な粒子であっても，他の粒子と共 存する場合には相互作用の結果として，種々の反応を起 して消隇し，別の種類の粒子が新圠発生することが珍 らしくないのである.このような素粒子間の相互転化こ そ, 様々な自然現象の基本的形態であると考えられる. このような素粒子間の素過程を基本的なるのと認める新 しい立場から見ると，古代原子の第一属性である分割不 可能性の方も，その本来の意味を失ってしまうことにな る. 例えば中性子が自発的に陽子と電子と中性微子とに 崩懐するという事実は，必ずしも中性子が陽子と電子々 中性微子の複合体であることを意味するものではない， 䒧しろ多くの場合, 崩壊と分割とは全く違った意味を持 つことを理解する必要がある.いいかえると，分割とい う言葉には古代原子のイメージが残存していて，今日わ れわれの持つ素粒子という概念には適合しない，例党ば 中性子と陽子の関係は決して一方的なるのでなく，陽子
が㓌電気を持った中間子を捕えて，中性子に転化するこ ともあれば，中性子が陽電気を持った中間子を捕えて陽 子に転化することもあるからである.

これを要するに，自然的世界は幾種類かの素粒子を基 本単位としていること，それ等の中のある特殊なるのが 多数集って物質を構成すること，素粒子の間の素過程が 集積して様々な自然現象をひき起すことなどを，われわ れの自然観の出発点として一応認めるほかないのである. 今日の自然観と十九世紀をでの科学者の自然観と違う所 は，単に原子の代りに素粒子を持ちこんだだけではない。 自然的世界の基本単位である素粒子自身が古代の原子の ように永久不変なものでなく，それ等の間で相互転化が 可能だということの方がかえって，素粒子の通有性を現 わしているのである. 素粒子の多くは不安定なるのであ り，原の中の少数の比較的に安定なものが集って，われ われの周囲の安定な物質世界を形づくっているに過ぎな いわれわれ人間の経験は長い間この狹い物質世界に局 限されていたがために，永久不変の原子という概念が不 動のものと思われたのである. 原子物理学の進歩に伴。 て, 人間の経験範囲が非常に抎大された結果として, 安 定な物質世界を構成する電子と陽子と中性子という三嘎 の粒子は, 次々と見出されてきた新しい糔子の仲間の中 で比較的に安定なものであったことがわかってきた．今 日の広い視野に立ってこの自然界を眺めるならば，素䊀 子が次々とできては消光，できては消光るのが，宇宙の 真相であることを認めざるを得ないであろう.

\section{2. 素粒子の背後にあるもの}

前節に述べたような考え方を認めた場合，われわれは 直ちに次の疑間に逢着する．素粒子自身が生隇流転する ものならば，この宇宙において恒常なるものは何である か.このような間に対してわれわれは今直ぐ決定的な答 を与えることはできないか子知れない，われわれのまだ 知らない，そして今日のいわゆる素粒子よりる一層基本 的で恒常なあるものがあって，素粒子の相互転化は結局 そのあるものの離合集散に過ぎないことが夺来わかるか 
も知れないあるいは反対にそういう恒常なものは結局 ないことがわかるかる知れない，自然法則自身には時間 空間を越えた恒常性普遍性はあっても，宇宙の実体には 恒常性はないのか子知れない，今のところでは，こうい うことを議論しても水掛論に終るであ万う。しかし今日 でもいえることは，物理学の進歩の結果として，法則と 実体とが密接な関係を持つことが，ますますはっきりわ かってきたことである.今日われわれが素粒子と呼んで いる所のるのが持っている疑うことのできない共通の属 性は，それ等がいずれる波動粒子の二重性を持つことで ある.この二重性は一方では素粒子が量子力学の諸法則 に従うことを意味するものと解釈されてきた．それと同 時に他方では，この二重性が四次元的なものであること から，素粒子は特殊相対論の諸要請を満すような対象で もあると見なされてきた：この両面を同時に其えた対象 を取扱うのに最む適当した数学的方法は，素粒子を量子 化された場として記述することであった．とれには先ず， 波動的側面の定式化として，特殊相対論の要求を満す古 典的な場の理論を一応つくっておき，次にこの古典的な 場を表わす通常の函数，即ち波動函数—子っと正確に いえば時空世界の各点に打汸る函数の值—を量子力学 的な演算子の集りと見な招すことによって，粒子的側面 を復活するというのが，場の量子諭の常套的手順であっ た. 実際場を量子化した場合にあらわれてくる基本的な 演算子には，その場に附随する素粒子の数を一個げけふ やすか，あるいは一個だけへらすという物理的な意味を 与えることができたのである.これ等の操作によって, 素粒子の一つもない状態, 即ちそういう意味での真宾と か無とかいうものから出発して，色々な種類の素粒子が それぞれ適当な数だけ存在している状態を自由に作るこ そができるのである. それは勿論，一般には数学的形式 的な意味でだけ可能なのであって，現実世界にはェネル ギーの保存の法則その他の多くの制約があるので，素粒 子が無から作られることもなく, 又多数の素粒子が共存 する現実の世界が無に帰してしまうこともない。しかし それにしても，場の量子論が現実世界を，それとは現実 的にはつながっていない非現実をるふくめた広大な背景 の中で見直すことを意味していることは確かである.

こういうことは勿論，場の量子論に限ったことではな い. 自然的世界を合理的に理解しようとするならば，ぞ うしても先ず現実世界をそれを含んだより広い世界の中 に置いて見なければなら妨。何故かといえば，自然の法 則性を知るということは，常にある法則に従う場合，従
わない場合の全体の中から，その法則に従う場合だけを 現実に対応するものとして選び出すことを意味している からである.この間の消息を明らかにするのに最も適当 した例として，古典力学における变分原理を取って見る. 一つの質点が二つの違った時刻のそれぞれに抢いて占め る点がわかっている場合, 途中の道筋は変分原理によっ て規定することができる．即ち現実にどれが実現される かは最初は知らないるのとして，とにかく色々な可能な 道筋を考え，その打の打のにいて作用積分を作って見 る. そこでもしもある特定の道笳に対して, 作用積分が 極值を取ることがわかれば，それが現実に質点の辿る道 筋だと判定するのである. 狭義の古典力学に限らず, 古 典的な場の力学をふくむ広い意味の古典力学を通じて. 基本法則を変分原理の形に書くことが可能であった. 量 子力学の基本法則もまた, 古典論的な变分原理に似た形 に書くことは可能であるが，筆者自身はこれについて今 までに試みられてきた定式化には疑間を持っている. 筆 者はむしろ変分原理自身が先ず量子力学の基本的な考え 方にもっとよく適当した形に転化すべきだと思っている. しかしこの点については, ここでは立ち大ることはやめ る.ここで強調したいことは, 変分原理に限らず, 一般 に物理的法則を定式化するということは，常に爸れに先 立ってこの法則によって拘束されない対象, いいかえれ ば現実をふくくんだ可能性の世界を想定しなければならな いことである. ロゴスによって秩序づけらるべきカオス を想定することなくしては, 理諭体係は構成できないの である.この意味に沶いて物理法則は常に混沌に限定を 与える選択規則の意味を持っている篔である. 素粒子諭 が現在の不満足な状態を脱却して, 物質世界を合理的に 記述する基本的な理論体系にまで飛躍するためには，現 在の素粒子論の諸法則がお互いにばらばらに，そしてし ばしば現実に順応するという消極的な動㙨だけから導入 されてきたという点をもっと根本的に反省する必要があ るように思われる、いいかれれ゙現実に存在し得る素粒 子全体の背景となるカオスは何であろうか，ぞのような 仕方でカオスの中にロゴスが導大されるであろうかとい う問題から出発し直すべきであると思われる.これにつ いては次節以下で改めてもっと具体的に論ずることにし よう。 